\title{
EFEKTIFITAS METODE LANGSUNG DALAM PENGAJARAN KETERAMPILAN BERBICARA BAHASA ARAB
}

\author{
Lina Marlina \\ Dosen Fakultas Informatika, Pendidikan Agama Islam dan Etika, \\ Telkom University Bandung
}

\begin{abstract}
Direct Method has currently become an alternative approach in teaching Arabic, to upgrade students' speaking ability. With this method, there will be direct communications in Arabic between teachers and students. In such condition, students will practice almost similar to their original (mother) language in a 2-way effective communication approach. The method was developed by experts of Arabic teaching following a disappointment to the result of teaching Arabic utilizing the approach of grammatical translation especially in relation to the critical needs of the active Arabic. In practice, the Direct Method shows its advantages. However at the same time the method produces challanges to teachers to improve their skills in applying the method properly. Skills and experiences of teachers in teaching with the direct method become very critical to overcome the challanges. The more skills and experiences the teachers, the easier and must be the better for them to overcome the challanges.
\end{abstract}

Kata Kunci: Metode Langsung, Bahasa Arab, Kemampuan Berbicara

\section{Pendahuluan}

Saat ini Bahasa arab bukan hanya merupakan bahasa komunikasi yang digunakan oleh masyarakat arab dan sekitarnya, tetapi juga merupakan bahasa kaum muslimin di Negara-negara Islam, karena merupakan bahasa Al-Quran, Hadits dan sumber-sumber ilmu keislaman yang menjadi pedoman hidup dan rujukan pokok kaum muslimin, oleh karena itu bahasa arab sangat berkaitan erat dengan kehidupan beragama kaum muslimin dimanapun mereka berada.

Bahasa arab selain bahasa yang erat hubungannya dengan dimensi keagamaan, tetapi juga merupakan bahasa ilmu pengetahuan dan bahasa pergaulan internasioanl di forumforum internasional seperti seminarseminar internasional, forum-forum sidang PBB dan juga bahasa komunikasi bisnis, perdagangan internasioanl dan bahasa media internasional.

Berdasarkan alasan tersebut selayaknya bahasa arab menjadi bahasa yang dibanggakan oleh kaum muslimin dan pembelajaran bahasa arab menjadi salah satu materi pokok di madrasah-madrasah dan perguruan-perguruan tinggi Islam di Indonesia.

Keterampilan berbahasa arab, sebagaimana bahasa asing lainnya meliputi empat komponen penting yang satu sama lain saling berkaitan yaitu, maharatu al istima' (keterampilan menyimak), maharatu al Kalam (keterampilan berbicara), maharatu al Kitabah (keterampilan menulis) dan maharatu al Qira'ah (keterampilan membaca) 
Maharatu al Kalam (keterampilan berbicara) merupakan komponen yang sangat penting dari empat komponen tersebut dan sebagai bukti keberhasilan dari komponen-komponen dasar lainnya, dalam komponen ini seseorang dituntut untuk mengungkapkan sesuatu secara spontan, sehingga dituntut pembiasaan dan penguasaan kosa kata yang memadai.

Dalam pencapaian kompetensi keterampilan berbicara siswa, seorang guru dituntut untuk mempersiapkan desain strategi pembelajaran yang efektif dan inovatif, karena desain strategi pembelajaran merupakan salah satu elemen dari empat unsur utama (yang mutlak harus serasi dan sesuai antara elemen yang satu dengan yang lain meskipun wujudnya berbeda) dari sebuah desain pembelajaran, yaitu Desain Materi (Content Design), Desain Kompetensi/Tujuan Pembelajaran/Hasil Pembelajaran (Competency, Learning Objectives Design), Desain Metode/Strategi/Teknik

Pembelajaran

(Instructional Strategies Design) dan Desain Evaluasi

(Evaluation Design).(Bermawy Munthe, 2009: 51)

Desain strategi pembelajaran sangat strategis karena ia merupakan cara bagaimana seorang guru sebagai ujung tombak perubahan melakukan usaha nyata untuk tercapainya kompetensi. Sehingga keberhasilan proses pembelajaran merupakan jaminan kualitas proses perubahan siswa sebagai out-put, atau dengan kata lain strategi pembelajaran adalah kunci peningkatan jaminan kualitas pembelajaran. (Bermawy Munthe, 2009: 53)
Desain strategi pembelajaran mutlak harus sesuai dengan kompetensi yang ingin dicapai guru dan siswa, strategi pembelajaran adalah alat atau media yang menentukan keberhasilan proses pembelajaran dan pencapaian kompetensi, suatu strategi atau metode pembelajaran dikatakan tepat jika ia sesuai dengan kecenderungan kompetensi sebagai totalitas hasil belajar yang akan dikembangkan, yaitu apakah bersifat kognetif, apektif atau psikomotorik.

Pada tataran realitas kebanyakan tenaga pendidik yang mengajar bahasa arab belum tentu berlatar belakang ilmu keguruan atau kependidikan, sehingga kurang memiliki kemampuan untuk mendesain strategi pembelajaran yang efektif sebagai penunjang keberhasilan proses pembelajaran dan pencapaian kompetensi siswa.

Pada sisi yang lain kebanyakan Guru bahasa Arab merasa kesulitan dalam menyusun strategi pembelajaran yang tepat disebabkan pemahaman siswa yang beragam, dan latar belakang pendidikan mereka yang berbeda,sehingga proses pembelajaran bahasa Arab berlangsung kurang optimal

Beragam strategi pembelajaran diujicobakan oleh para pengajar bahasa arab agar menemukan strategi pembelajaran yang tepat untuk mencapai kompetensi yang diharapkan, namun tetap saja stigma yang muncul tentang belajar bahasa arab adalah sulit dan membosankan.

Berdasarkan pengamatan penulis, salah satu strategi pembelajaran yang banyak digunakan di madrasah-madrasah yang berbasis pondok pesantren (Boarding school) dalam pencapaian kompetensi keterampilan berbicara 
bahasa arab adalah metode langsung, dalam metode ini terjadi komunikasi dua arah secara aktif antara seorang guru dan siswa selama proses belajar mengajar berlangsung, dengan membiasakan penggunaan bahasa arab sebagai bahasa pengantar utama.

Metode ini dikembangkan atas dasar asumsi bahwa proses belajar bahasa kedua atau bahasa asing sama dengan belajar bahasa ibu, yaitu dengan penggunaan bahasa secara langsung dan intensif dalam komunikasi, sedangkan mengarang dan membaca dikembangkan kemudian. Oleh karena itu pelajar harus dibiasakan berpikir dengan Bahasa Target dan penggunaan bahasa ibu pelajar dihindari sama sekali. (Bermawy Munthe, 2009: 46) Berdasarkan pengalaman penulis di lapangan, rendahnya kemampuan berbicara siswa menggunakan bahasa arab dalam belajar rata-rata dihadapi oleh sejumlah siswa yang memiliki minat yang rendah untuk belajar. Sehingga siswa kurang mampu berbicara menggunakan bahasa arab. Hal ini disebabkan karena guru dalam proses belajar mengajar hanya menggunakan metode ceramah dan hanya terpaku dengan adanya buku panduan serta lembar kerja siswa (LKS) tanpa menggunakan startegi dan metode pengajaran yang tepat.

Bahasa Arab sebagai salah satu bahasa Asing di Indonesia menduduki posisi yang sangat strategis terutama bagi umat Islam, Hal ini bukan saja karena bahasa Arab digunakan dalam ritual keagamaan seperti shalat, khutbah jum'at, dalam berdo'a dan lain-lain, tetapi juga menjadi bahasa ilmu pengetahuan dan bahasa pergaulan internasional.
Kenyataan yang dihadapi
bahwa sesungguhnya kondisi pengajaran bahasa Arab di madrasahmadrasah/ sekolah-sekolah dan perguruan tinggi di Indonesia masih dihadapkan pada berbagai kendala dan tantangan. Kendala atau tantangan tersebut paling tidak dapat terlihat salah satunya dari segi edukatif. Pengajaran bahasa Arab masih relatif kurang ditopang oleh faktor-faktor pendidikan yang memadai. Faktor-faktor disini diantaranya factor kurikulum,termasuk di dalamnya orientasi dan tujuan, materi dan metodologi pengajaran serta sistem evaluasi tenaga edukatif, sarana dan prasarana.

Pengajaran bahasa Arab yang selama ini berjalan di berbagai madrasah atau sekolah pada umumnya masih menitik beratkan kepada metode gramatikal terjemah dan masih relatif kurang ditopang oleh faktor-faktor pendidikan pengajaran yang memadai. Tidak dipungkiri bahwa kurikulum memegang peranan penting bagi perjalanan sebuah proses belajar mengajar.

Namun demikian, kurikulum yang selama ini diformat oleh para pemegang kebijakan pendidikan bahasa Arab seringkali dinilai kurang produktif, terlalu gemuk dengan materi dan tidak terorientasi dengan kompetensi akhir yang harus dimiliki oleh peserta didik. Syaratnya materi yang harus dipasok ke dalam sel-sel otak peserta didik, memotivasi para pengajar untuk hanya bertugas sebagai penyampai pokok bahasan, sehingga daya kreasi pengajar tumpul dalam mengadakan pengayaan strategi pengajaran Pembelajaran Bahasa Arab yang diselenggarakan pada gilirannya 
kemudian hanyalah berpola untuk memindahkan isi (content transmission) dari pengajar ke peserta didik. Hal ini tentu saja membuat proses belajar mengajar menjadi bersifat monoton, satu arah dari pengajar ke peserta ajar (one way communication), tidak diarahkan ke partisipatori total peserta didik. Dan akhirnya, pola pengajaran menjadi sangat monolog dan menjemukan.

Masalah pendidikan dan pengajaran merupakan masalah yang sangat kompleks dimana banyak faktor yang ikut mempengaruhinya. Salah satu faktor tersebut adalah guru. Guru merupakan komponen pengajaran yang memegang peranan penting dan utama, karena keberhasilan proses belajar mengajar sangat ditentukan oleh faktor guru.

Sebagai pengajar bahasa Arab yang baik seyogyanya mengetahui dengan pasti tujuan yang hendak dicapai oleh pengajaran bahasa itu, mengetahui apa yang hendak di ajarkan untuk mencapai tujuan itu, dan mengetahui bagaimana membawa-kannya di depan kelas sehingga tujuan itu bisa tercapai pada waktu yang telah di tentukan dalam kurikulum, dan mengetahui pula kapan masing-masing tahapan diajarkan.

Dengan perkataan lain tujuan pengajaran bahasa Arab akan menentukan materi yang harus diajarkan, dan menentukan pula sistem dan metode yang hendak dipergunakan. Di samping itu, hal lain yang harus dipertimbangkan dan diprioritaskan dalam pengajaran adalah faktor ketrampilan bahasa.

Mata pelajaran bahasa arab merupakan mata pelajaran yang dipel-ajari di sekolah-sekolah islam berbasis pesantren, karena bahasa arab merupakan alat utama dalam mempelajari sumber-sumber rujukan ajaran Islam seperti, al Quran, hadis dan kitab-kitab karya para ulama Islam terdahulu maupaun kontemporer.

Tuntutan dalam mempelajari bahasa arab tidak cukup hanya sekedar sebagai alat untuk menerjemahkan sumber-sumber rujukan ajaran Islam, tetapi juga harus dikembangkan menjadi bahasa komunikasi aktif sehingga menjadi identitas yang dibanggakan bagi sebuah lembaga pendidikan Islam.

Untuk meningkatkan kemampuan peserta didik dalam berbicara bahasa arab diperlukan metode pengajaran yang tepat yang dapat mendorong mereka supaya mengguna-kan bahasa arab sebagai bahasa komunikasi aktif dalam pembelajaran dan percakapan seharihari.

Dalam prakteknya banyak sekolah-sekolah Islam maupun pesantren menghadapi kendala untuk memilih metode apa yang sesuai dengan keberagaman siswa-siswi yang ada di sekolah atau pesantren tersebut, begitu juga buku-buku pegangan bahasa arab yang tepat agar para siswa mampu berbicara bahasa arab secara aktif.

Salah satu metode yang banyak dipakai dalam pengajaran bahasa arab di sekolah-sekolah Islam dan pesantren adalah metode langsung (athariqah al mubasyiroh) karena metode ini mendorong terjadinnya komunikasi langsung antara pendidik dan peserta didik dengan menggunakan bahasa arab.

Pada umumnya masayarakat muslim di Indonesia mengukur keberhasilan suatu pesantren dalam pengajaran bahasa arab yaitu dari kemampuan siswa-siswinya dalam 
berbicara bahasa arab secara aktif, hal ini terlihat dari antusias masyarakat yang menyekolahkan anak-anak mereka ke pesantren yang dianggap berhasil dalam pengajaran bahasa arab seperti Pondok Modern Gontor.

Pada kenyataannya di sebagian besar pondok pesantren lebih banyak menghafal kaidah-kaidah bahasa arab seperti kitab jurumiyah, alfiyah, mantiq dan lain-lain, sementara percakapan bahasa arabnya kurang diperhatikan, sehingga kemampuan bahasa para santri sangat pasif dan tidak mampu mengembangkan kalimat-kalimat bahasa arab karena hanya terpaku pada kaidah-kaidah saja.

\section{Terminologi Metode Langsung dalam Pengajaran Keterampilan Berbicara}

Proses belajar mengajar merupakan interaksi yang dilakukan antara guru dengan peserta didik dalam suatu pengajaran untuk mewujudkan tujuan yang ditetapkan, dalam sebuah hadis rasulullah saw. terdapat suatu isyarat sebagai berikut, Rasulullah saw. bersabda, "Bagi se-gala sesuatu itu ada metodenya, dan metode masuk surga adalah ilmu." (H.R. Dailami). Hadits tersebut menegaskan bahwa untuk mencapai sesuatu itu harus menggunakan metode atau cara yang ditempuh termasuk keinginan masuk surga. Dalam hal ini ilmu termasuk sarana atau metode untuk memasukinya.

Metode dalam bahasa arab disebut Thariqah, adalah rencana menyeluruh yang berkenaan dengan penyajian materi bahasa secara teratur, tidak ada satu bagiannya yang bertentangan dengan bagian yang lain dan semuanya berdasarkan pada approach (pendekatan) yang telah ditentukan. Jika approach bersifat axiomatic, metode bersifat prosedural. Sehingga dalam satu pendekatan bisa saja terdapat beberapa metode. Misalnya, ada beberapa faktor yang mempengaruhi penyajian materi pelajaran diantaranya latar belakang bahasa siswa, dan bahasa asing yang dipelajarinya sehingga mengakibatkan perbedaan metodologis.

Pengajaran bahasa Arab untuk orang Indonesia akan berbeda secara metodologis dengan pengajaran bahasa Arab untuk orang asing lainnya. Umur peserta didik, latar belakang sosio-kultural, pengalamannya dengan bahasa arab atau bahasa asing lainnya sebelumnya merupakan faktor-faktor yang mempengaruhi metode. Dalam pembelajaran memilih suatu metode, bisa terjadi beberapa metode didasarkan atas approach yang sama. (Sumardi, 12)

Berdasarkan tujuan, yakni pembelajaran aktif berpusat pada siswa jadi penulis menggunakan Metode Langsung (Thariqoh Mubasyirah) dalam pembelajaran bahasa Arab. Metode apa pun yang digunakan oleh pendidik atau guru dalam proses pembelajaran, yang perlu diperhatikan adalah akomodasi menyeluruh terhadap prinsip-prinsip KBM, diantaranya:

Pertama, berpusat pada anak didik (student oriented). Guru harus memandang anak didik sebagai sesuatu yang unik, tidak ada dua orang anak didik yang sama, sekalipun mereka kembar. Satu kesalahan jika guru memperlakukan mereka secara sama. Gaya belajar (learning style) anak didik harus diperhatikan. 
Kedua, belajar dengan melakukan (learning by doing) supaya proses belajar itu menyenangkan, guru harus menyediakan kesempatan kepada anak didik untuk melakukan apa yang dipelajarinya, sehingga ia memperoleh pengalaman nyata.

Ketiga, mengembangkan kemampuan sosial. Proses pembelajaran dan pendidikan selain sebagai wahana untuk memperoleh pengetahuan, juga sebagai sarana untuk berinteraksi sosial (learning to life together).

Keempat, mengembangkan keingintahuan dan imajinasi. Proses pembelajaran dan pengetahuan harus dapat memancing rasa ingin tahu anak didik juga mampu memompa daya imajinasi anak didik untuk berfikir kritis dan kreatif.

Kelima, mengembangkan kreativitas dan ketrampilan memecahkan masalah. Proses pembelajaran dan pendidikan yang dilakukan oleh guru bagaimana merangsang kreativitas dan daya imajinasi anak untuk menemukan jawaban terhadap setiap masalah yang dihadapi anak didik.

Dalam proses pembelajaran bahasa kedua, bahasa itu dipelajari melalui asosiasi langsung antara kata atau frase dengan benda dan perbuatan atau intervensi bahasa pertama.Pembelajar harus dapat menguasai kegiatan menyimak bahasa tersebut melalui latihan sesering mungkin. Pembelajaran bahasa harus bermula dari pengenalan benda-benda dan perilaku yang ada di sekeliling pembelajar, misalnya benda-benda yang ada di dalam kelas. Ketika proses belajar berlangsung, pembelajar mengkomunukasikan apa yang dilihatnya dengan menggunakan bahasa kedua (bahasa Arab).

Untuk menghindari penggunaan terjemahan,pengajar dapat memanfaatkan gambargambar. Penjelasan mengenai kosakata baru dilakukan melalui para frase dalam bahasa kedua (bahasa Arab), gerak-gerik tubuh, atau dengan menunjukkan benda yang dimaksud. Kaidah bahasa tidak diajarkan secara terpisah atau tersendiri, tetapi dipelajari oleh pembelajar melalui pelatihan. Mereka akan membuat simpulansimpulan mengenai tata bahasa melalui metode induktif. Pengembangan ketrampilan membaca diintegrasikan dengan ketrampilan berbicara karena bahasa pada dasarnya adalah ujaran. Budaya diartikan lebih dari sekedar seni.

Metode langsung berasumsi bahwa belajar bahasa yang baik adalah belajar langsung menggunakan bahasa yang diajarkan secara intensif dalam komunikasi, sehingga terjadi interaksi langsung antara pendidik dan peserta didik dengan menggunakan bahasa tersebut. Penggunaannya di kelas harus seperti penutur asli.

Metode ini lahir sebagai reaksi terhadap penggunaan metode nahwu wa tarjamah yang mengajarkan bahasa seperti bahasa mati. Sebelumnya sejak tahun 1850 telah banyak muncul propaganda yang mengampanyekan agar menjadikan pengajaran bahasa asing itu hidup, menyenangkan dan efektif. Propaganda ini menuntut adanya perubahan yang mendasar dalam metode pengajaran bahasa asing. Sehingga secara cepat lahirlah metode pembelajaran baru yang disebut Metode Langsung. (Abdul Hamid dkk., 2008: 23) 
Menurut Moulton (1963), bahasa yang juga dipengaruhi strukturalisme memiliki lima karakteristik kunci yaitu,

a. Bahasa itu ujaran, bukan tulisan.

b. Bahasa itu seperangkat kebiasaan.

c. Ajarkanlah bahasa, bukan tentang bahasa.

d. Bahasa adalah sebagaimana dikatakan oleh penutur asli, bukan seperti yang dipikirkan orang bagaimana seharusnya berbicara.

e. Bahasa itu berbeda-beda.

Pengajaran yang khas dalam pendekatan ini adalah sebagai berikut :

a. Menyajikan butir bahasa yang harus dipelajari, dengan memberikan demonstrasi yang jelas untuk maknanya melalui sarana nonverbal.

b. Memberikan model pola-pola bahasa target dengan sejumlah contoh.

c. Pelatihan bentuk substitusi progresif dilakukan siswa seluruh kelas, diikuti dengan siswa kelas yang dibagi dua, kemudian perseorangan.

Melakukan

pengulangan menggunakan versi interogatif struktur bahasa sasaran.Tahap terpenting dalam metode ini adalah penyajian dan pelatihan, karena dilakukan secara eksklusif dalam bahasa sasaran,penyajian penting sekali dilakukan sejelas mungkin. (Furqanul Aziez dan Chaedar Alwasilah, 1996: 21-22)

d. Prinsip belajar bahasa komunikatif. Bahasa adalah membantu pembelajar mampu menggunakan bahasa target. Tujuan ini bisa dicapai dengan mengikuti berbagai jalan, dan dengan menggunakan berbagai pendekatan pengajaran.

Untuk mencapai tujuan tersebut seorang guru harus mengetahui prinsip-prinsip belajar bahasa yang kemudian harus diwujudkan ke dalam kegiatan pengajaran mereka, menjadikan aspek-aspek tersebut sebagai petunjuk pengajarannya.

Prinsip-prinsip belajar bahasa yakni sebagai berikut:

a. Pembelajar akan belajar bahasa dengan baik bila ia diperlakukan sebagai individu yang memiliki kebutuhan dan minat.

b. Pembelajar akan belajar bahasa dengan baik bila ia diberikan kesempatan untuk berpartisipasi dalam penggunaan bahasa sasaran secara komunikatif dalam berbagai aktivitas.

c. Pembelajar akan belajar bahasa dengan baik bila ia secara sengaja memfokuskan pembelajarannya kepada bentuk keterampilan dan strategi untuk mendukung proses pemerolehan bahasa.

d. Pembelajar akan belajar bahasa dengan baik bila ia dibeberkan dalam data sosiokultural dan pengalaman langsung dengan budaya menjadi bagian dari bahasa sasaran.

e. Pembelajar akan belajar bahasa dengan baik bila ia menyadari akan peran dan hakekat bahasa dan budaya.

f. Pembelajar akan belajar bahasa dengan baik bila ia diberi umpan balik yang tepat yang menyangkut kemajuan mereka.

g. Pembelajar akan belajar bahasa dengan baik bila ia diberi 
kesempatan untuk mengatur pembelajaran mereka sendiri.1

\section{PEMBAHASAN}

Secara historis perkembangan pengajaran bahasa dapat diklasifikasikan kepada lima periode, yaitu : pertama periode masa Romawi kuno dan abad pertengahan, kedua periode Renaissanse, ketiga periode abad ke XVII, keempat periode abad ke XIX. dan kelima periode abad ke XX. Dengan memperhatikan periodesasi tersebut di atas menunjukkan bahwa manusia itu tidak pernah puas dengan hal yang monoton, akan tetapi selalu mencari sesuatu yang baru, maka ketika itu muncullah sesuatu yang terbaru yang dianggap lebih tepat berlaku masa itu. Namun pada akhirnya berubah menjadi usang, membosankan dan bersifat trasdisional ketika ditemukan lagi sesuatu yang terbaru yang sangat relevan dengan tututun berikutnya.

Di Inggris antara tahun 1899 1924, Direct Method (metode langsung) dalam sejarah merupakan metode yang paling populer pada masa itu. Dalam arti bahwa metode dianggap sebagai salah satu aspek pengajaran yang sangat urgen, walaupun pada dasarnya semua metode itu baik, namun metode langsung dianggap sangat signifikan untuk diterapkan dan dikembangkan pada masa itu.

Namun pada akhirnya metode ini ditinggalkan dan berpindah kembali kepada metode tradisional dikarenakan tenaga edukatifnya tidak mampu melaksanakan metode tersebut secara kualitatif dan kuantitatif. Maka sebagai konsekuensi atas lahirnya metode

1Ibid, hlm. 28-32. lain yang disebut dengan Metode Grammar Transliteration (Metode Gramatika Terjemah) dan sekaligus meninggalkan metode pengajaran sebelumnya, yaitu Direct Method (Metode Langsung), yang lahir di Prancis. Walaupun metode Direct Methode pernah ditinggalkan tetapi metode ini tetap digunakan dalam proses belajar mengajar bahasa asing sampai saat ini. Karena metode ini dalam aplikasinya mempermudah peserta didik lebih komunikatif.

Walaupun ada perbedaan pendapat mengenai metode ini dari segi fungsi dan efisiensi, disisi lain nampak metode ini memiliki pengaruh yang cukup luas dalam perkembangan bahasa Arab. Terlihat dari prosesnya, peserta didik langsung memperaktekkan dan melatih lidahnya dalam berbahasa.

\section{Ciri-Ciri Metode Langsung}

Metode langsung adalah satu dari beberapa metode yang digunakan dalam pengajaran bahasa arab ataupun bahasa asing lainnya. Untuk membedakannya dari metodemetode yang lain adalah dengan ciriciri sebagai berikut,

1) Materi pelajaran pertamatama diberikan kata demi kata, setelah itu beralih kepada struktur kalimat. Pertama-tama diajarkan pengenalan huruf-huruf dengan tipikal tiap huruf yang berbeda (memperhatikan makhārij al-hurūf) seperti ط طada , س, ذ, ش, , , ص

Keenam huruf tersebut masing-masing memiliki makhārij al-hurūf yang berbeda tetapi masing-masing dalam penyebutannya mengandung huruf "s" atau mendekatinya. Setelah hal ini 
dianggap rampung, barulah memasuki tahap-tahap pembentukan struktur kata ataupun menyusun hurufhuruf di atas dalam sebuah struktur kalimat yang sering dipakai ataupun dialami seperti,

dan المد ر سة , المد رس , الدرس sebagainya.

2) Gramatika diajarkan hanya bersifat sambil lalu, siswa tidak dituntut menghafal rumus gramatika, tapi yang utama adalah mampu mengucapkan secara baik.

Cara mengajarkan gramatika hanya sambil lalu sifatnya, maksudnya kaidah-kaidah yang ada tidak harus dihafal, tetapi dibentuk situasi yang sedemikian rupa dan diperaktekkan langsung secara lisan.

Dibedakan dengan teknik pengajaran bahasa Arab konvensional yang mengutamakan pengajaran gramatika dengan penggunaan contoh yang sangat minim kosa katanya, seperti ضرب, dan sebagainya. Hal ini mengakibatkan bahasa Arab hanya dipahami dalam kaidah-kaidah dan membuat peserta didik pasif dalam perkembangan bahasa Arab yang seakan-akan perkembangannya tidak terletak pada sisi gramatikalnya.

3) Dalam proses pengajaran senantiasa menggunakan alat bantu ataupun alat peraga baik alat peraga langsung ataupun tidak langsung (benda tiruan). Juga biasanya menggunakan simbol-simbol ataupun gerakan-gerakan tertentu. Sebagai contoh, seorang guru mengisyaratkan pulpen yang ada ditangannya kemudian menyebutkan bahasa Arabnya, atau bisa juga dengan menunjukkan gambarnya.

4) Setelah memasuki kelas, siswa atau peserta didik benar-benar dikondisikan untuk menerima dan bercakap-cakap dalam bahasa Arab atau bahasa asing dan dilarang menggunakan bahasa lain.

Misalnya, seorang guru memasuki kelas dan mengucapkan salam ataupun menanyakan kabar mereka, menanyakan tanggal atau hari apa dan seterusnya, semuanya itu dengan menggunakan bahasa Arab.

5) Aktifitas belajar secara klasikal banyak dibimbing guru langsung praktek di dalam kelas, sedangkan di luar kelas peserta didik ditekankan untuk mempraktekkannya dengan kawan-kawan setingkat.

6) Porsi latihan mendengarkan lebih banyak untuk kemudian ditirukan. Ini bertujuan mempercepat peserta didik untuk mencapai pengetahuan bahasa secara otomatis.

7) Pada pengajaran bacaan, harus diberikan secara lisan terlebih dahulu, dengan jalan menunjukkan atau menuliskan kata-kata yang sukar satu per satu, kemudian menghubungkannya dalam bentuk kalimat dan alinea.

8) Sejak awal murid telah dilatih berfikir dalam bahasa Arab. 
Hal ini akan bermanfaat sekali dalam perkembangan selanjutnya.

Dari beberapa ciri terebut, maka nampak bahwa ada sejumlah hal yang perlu diperhatikan pendidik atau guru dengan peserta didik. Seorang guru harus benar-benar meguasai materi dan memahami betul metode yang sedang ia terapkan dalam pengajaran. Sedangkan murid harus aktif mengikuti penjelasan gurunya dan membiasakannya pada praktek.

Karena proses pelaksanaan metode ini amat bertumpu pada guru, maka seorang guru dituntut agar selain menguasai materi, juga kemahiran mendemontrasikan alat peraga ataupun penggunaan contoh dan isyarat, agar siswa memberikan perhatian dan ikut aktif untuk mengucapkan kata-kata yang diminta oleh guru.

\section{Kelebihan dan Kekurangan Metode Langsung}

Kelebihan Metode Langsung yang ditemukan dalam praktek pembelajaran bahasa Arab adalah sebagai berikut :

1. Siswa terampil menyimak dan berbicara.Dengan menggunakan metode langsung,siswa-siswi terbiasa menyimak guru berkomunikasi menggunakan bahasa arab sehingga kemampuan mereka menyimak dan berbicara bahasa arab sangat terlatih.Setiap hari mereka berusaha berbicara bahasa arab sedikit demi sedikit dengan sesame temannya dan akhirnya mereka terampil berbicara bahasa arab dalam kehidupan mereka sehari-hari.

2. Siswa menguasai pelafalan dengan baik seperti atau mendekati penutur asli.Setiap hari guru memberikan contoh bagaimana pengucapan bahasa arab yang baik dan benar sesuai dengan makhorijul hurufnya dan intonasi pelafalannya.bagaimana intonasi kalimat berita,kalimat tanya,kalimat seru dan yang lainnya,sehingga siswa mampu melafalkan huruf-huruf dan kalimat bahasa arab yang benar dengan intonasi yang sesuai.

3. Siswa mengetahui banyak kosa kata dan pemakaiannya dalam kalimat. Penguasaan kosa kata dengan menggunakan metode langsung bukan dengan cara menghapal kosa kata, tapi penguasaan kosa kata langsung dengan mempraktekkannya dalam proses belajar mengajar, karena setiap hari siswa mendengar guru berbicara bahasa arab akhirnya secara tidak langsung mereka jadi paham dan penguasaan kosa katanya bertambah banyak dan mereka langsung mempraktekkan kosa kata tersebut di dalam kelas.

4. Siswa memiliki keberanian dan spontanitas dalam berkomunikasi karena dilatih berfikir dalam bahasa arab secara langsung sehingga tidak terhambat oleh proses penerjemahan. Dengan menggunakan metode langsung secara spontan siswa memiliki keberanian untuk berbicara bahasa arab karena mereka terbiasa mendengar dan berbicara bahasa arab setiap hari, mereka tidak terhambat oleh makna kata atau terjemahan dan merekapun tidak terlalu memikirkan kaidah nahwu, sharaf, marfu', manshub, majrur, mereka semangat percaya diri dan penuh 
keberanian untuk terus berbicara bahasa arab.

5. Siswa menguasai tata bahasa secara fungsional tidak sekedar teoritis, artinya berfungsi untuk mengontrol kebenaran ujarannya. Penguasaan tata bahasa atau kaidah nahwu sharaf dengan menggunakan metode langsung bukan dengan menghapal jurumiyah,alfiyah atau kitabkitab qowaid lainnya, tapi justru dengan berbicara langsung, temen-temen siswa yang lainnya bisa mengontrol kebenaran ujaran temennya, apakah sesuai dengan kaidah nahwu sharaf atau tidak, jadi mereka menguasai kaidah nahwu sharaf langsung dari praktek bicara dan kaidah nahwu sharaf tidak menghalangi mereka untuk terus berbicara bahasa arab.

Adapun kekurangan Metode Langsung yang ditemukan dalam proses pembelajaran adalah sebagai berikut :

1. Idealnya metode langsung diterapkan pada siswa yang memiliki kemampuan dasar bahasa arab, atau setidaknya pernah belajar bahasa arab sebelumnya, oleh karena itu latar belakang siswa yang heterogen akan menjadi kendala dalam penerapan metode langsung.

Sebagian siswa ada yang memiliki kemampuan bahasa arab yang cukup baik, sehingga kadang-kadang dia kurang memperhatikan penjelasan guru ketika guru sedang menjelaskan pelajaran yang belum dimengerti oleh siswa yang tidak memiliki dasar bahasa arab sehingga timbul kegaduhan di dalam kelas.
Di sisi lain siswa yang belum paham perlu penjelasan guru berulang-ulang, sementara yang sudah paham merasa jenuh dan bosan karena guru terus mengulang kosa kata tersebut,maka disinilah diperlukan sosok guru ideal yang bisa mengayomi seluruh siswa,guru bisa saja memanfaatkan kemampuan siswa yang pintar untuk belajar berbagi ilmunya dan mengajari temannya yang belum paham sehingga suasana kelas menjadi hidup dan dinamis.

2. Siswa lemah dalam kemampuan membaca dan memahami karena materi dan latihan ditekankan pada bahasa lisan. Fokus pembelajaran bahasa arab dengan menggunakan metode langsung adalah kemampuan menyimak dan berbicara, latihan-latihan lebih banyak ditekankan pada bahasa lisan sehingga kemampuan membaca dan memahami serta menerjemahkan teks yang mereka baca kurang diperhatikan.

Dalam belajar bahasa arab siswa harus menguasai empat keterampilan yaitu, keterampilan menyimak, keterampilan membaca, keterampilan berbicara dan keterampilan menulis. Dalam pengajaran bahasa arab dengan menggunakan metode langsung keterampilan yang lebih ditekankan adalah keterampilan menyimak dan berbicara, sehingga karena terbatas waktu dan juga materi pelajaran yang cukup banyak, maka keterampilan membaca dan menulis kurang tersentuh atau 
prosentase waktunya hanya sedikit.

3. Memerlukan guru yang ideal dari segi keterampilan berbahasa dan kelincahan dalam penyajian pelajaran, dan realitasnya Sumber Daya Manusia seperti ini tidak mudah. Dalam setiap mata pelajaran memang sangat diperlukan guru ideal yang menguasai materi pelajaran dan mampu menyajikan pelajaran dengan baik dan menarik dan ini merupakan tantangan terbesar dalam pengajaran bahasa arab dengan menggunakan metode langsung, karena realitasnya sumber daya manusia yang memiliki kemampuan ideal sangat jarang.

Kendala yang lain, guru bahasa arab yang belajar bahasa arab di Indonesia baik di sekolahsekolah Islam maupun di pesantren akan jauh berbeda dengan guru bahasa arab yang pernah belajar langsung di Negara arab, tentu saja kefasihan berbicara seorang guru akan sangat berpengaruh pada kefasihan berbicara para siswa.

Biasanya latar belakang pendidikan seorang guru juga pengalaman mereka dalam mengajar bahasa arab, sangat berpengaruh pada kreatifitas dan kelincahan guru dalam penyajian materi pelajaran, guru yang pernah belajar di Gontor misalnya, tentu dalam pengajaran bahasa arabnyapun dipengaruhi pengalamannya selama belajar di Gontor. Begitu pula guru yang pernah mondok di pesantren tradisional mereka biasanya lebih menekankan pada penguasaan kaidah nahwu dan sharaf. Dan tentunya akan jauh berbeda dengan guru yang pernah mondok di pesantren tradisional, kemudian dia juga pernah belajar di Gontor, ditambah lagi dia meneruskan pendidikannya ke Timur Tengah,tentu pengajaran bahasa arabnya akan lebih dinamis dan lebih kreatif karena pengalaman adalah guru yang paling baik.

4. Tidak bisa dilaksanakan dalam kelas besar. Pengajaran bahasa arab dengan menggunakan metode langsung sangat menekankan pada penguasaan siswa berbicara bahasa arab, dan latihan dalam kemampuan berbicara ini memerlukan waktu yang cukup lama dan hal ini dalam kenyataannya sulit dipraktekkan dalam kelas yang jumlah siswanya cukup banyak, karena satu persatu siswa harus maju ke depan kelas dan praktek berbicara bahasa arab,dan ketika jumlah siswanya banyak terbentur dengan waktu yang tersedia.

Pengajaran bahasa arab dengan menggunakan metode langsung, sangat menekankan supaya seluruh siswa bisa menguasai materi pelajaran dan mereka bisa mempraktekkannya dengan teman-temannya di depan kelas. Dari hasil observasi penulis ketika jumlah siswa terlalu banyak yaitu 39 orang, maka ketika ada dua orang siswa yang berdialog di depan kelas dan guru memperhatikan kedua siswa tersebut, maka siswa-siswa yang lain ribut dan mengobrol. Seharusnya guru memberikan tugas latihan kepada siswa yang lain sehingga suasana kelas tetap tenang. 
5. Tidak

diperbolehkannya

pemakaian bahasa ibu siswa bisa berakibat terbuangnya waktu untuk menjelaskan makna satu kata abstrak, dan terjadinya kesalahan persepsi atau penafsiran pada siswa. Karena pembelajaran bahasa arab dengan metode langsung jika dicampur dengan bahasa ibu akan membuat para siswa lamban dalam memahami bahasa arab dikarenakan setiap kalimat yang ia dengar harus memikirkan terjemahannya terlebih dahulu.

Dalam penerapan metode langsung seorang guru berusaha untuk selalu menggunakan bahasa arab,menerjemahkan teks bacaan satu persatu itu sangat dihindari,sehingga disini diperlukan kesabaran dan waktu yang cukup lama. Dan untuk menjelaskan makna suatu kalimat tentu guru membutuhkan alat peraga seperti gambar atau menunjukkan benda-bendanya langsung, sangat diperlukan kreatifitas dan kelincahan guru dalam menggunakan metode langsung.

6. Model latihan menirukan dan menghafalkan kalimat-kalimat yang kadangkala tidak bermakna atau tidak realistis karena tidak kontekstual, bisa menyebabkan kebosanan, sehingga tidak sedikit yang belajar bahasa arab tidak sampai tuntas karena mengalami kebosanan tersebut.

Siswa dituntut untuk bisa berbicara bahasa arab, dan tentu dalam keterampilan berbicara ini siswa harus latihan menirukan dan melafalkan kalimat-kalimat dalam bahasa arab dengan benar,sehingga ketika mereka

$$
\begin{aligned}
& \text { praktek berdialog dengan } \\
& \text { temannya mereka mampu } \\
& \text { melafalkan kalimat-kalimat } \\
& \text { tersebut dengan benar dan } \\
& \text { dengan intonasi yang sesuai. }
\end{aligned}
$$

\section{Cara Menanggulangi Hambatan- hambatan Dalam Penerapan Metode Langsung.}

Dengan pengalaman yang dimiliki oleh seorang guru dalam mengajar, ia akan mampu menanggulangi hambatan-hambatan yang dihadapinya dalam penerapan metode langsung.

Begitu juga halnya guru bahasa arab harus mencoba menanggulangi masalah-masalah tersebut berdasarkan pengalaman mengajar yang ia peroleh dengan langkahlangkah sebagai berikut,

1. Siswa dites secara lisan terlebih dahulu, sehingga dapat dikelompokkan sesuai dengan kemampuan dan latar belakang masing-masing, hal ini akan memudahkan seorang guru dalam mengajar, sehingga akan disesuaikan dengan kemampuan para siswa.

2. Membaca teks berbahasa arab merupakan komponen yang cukup penting dalam pembelajaran bahasa arab, oleh karena itu apabila siswa lemah dalam membaca teks-teks bahasa arab, bisa diintegrasikan antara berbicara bahasa arab yang benar dengan membaca teks-teks bahasa arab pada saat pembelajaran berlangsung. Hal ini tidak akan saling melemahkan yang lain, karena antara berbicara dan membaca memiliki keterikatan antara satu dengan yang lainnya.

3. Untuk menanggulangi kelangkaan SDM diperlukan 
kaderisasi

secara

berkesinambungan, siwa-siswa yang berprestasi bisa diberikan beasiswa untuk melanjutkan sekolah sampai kuliah pada jurusan bahasa arab dan didorong melanjutkan ke Negara-negara arab, dan pada saat lulus mereka direkrut oleh pesantren dengan gaji dan fasilitas yang cukup.

4. Pada dasarnya jumlah siswa yang lebih kecil akan memudahkan pengajar dalam memantau perkembangan siswa, namun untuk even-even tertentu seperti ceramah umum, seminar atau diskusi bisa saja dilakukan dalam kelas yang besar, dan even seperti ini sesekali juga diperlukan.

5. Meskipun pada dasarnya dalam metode ini pengajar tidak boleh menggunakan bahasa ibu dalam menyampaikan materi pelajaran, namun pada kenyataannya tidak selalu konsisten demikian. Pengajar kadang-kadang menerjemahkan kata-kata asing atau sulit ke dalam bahasa ibu jika diperlukan, hal ini tidak mengurangi kelancaran dalam berkomunikasi.

Kenyataan seperti ini memang sering kali terjadi. Kenyataan bahwa bahasa Arab memiliki perbedaan yang unik dibanding bahasa asing lainnya. Seperti pada bentukan kalimatnya ataupun pada perpaduan katakata yang merubah arti dasar kata tersebut, oleh karena itu guru terpaksa harus menerangkannya dengan bahasa ibu.

Sebagai contoh seperti : تحت العنوان yang berarti dengan

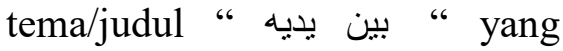

berarti “ dihadapannya “. Dari contoh yang dikemukakan jelas bahwa kadang ada yang membuat pengajar terpaksa menjelaskan dengan bahasa ibu untuk menjelaskan arti yang benar.

6. Untuk mengatasi kebosanan dibutuhkan kreatifitas seorang guru dalam mengajar dengan cara-cara yang inovatif, misalnya diselingi dengan kisahkisah atau nyanyian-nyanyian nasyid dalam bahasa arab, atau menggunakan sarana-sarana multimedia yang menarik.

\section{PENUTUP}

Dari uraian tersebut, penulis dapat menyimpulkan bahwa, Metode langsung merupakan metode yang cukup efektif dalam meningkatkan kemampuan berbicara siswa.

Metode ini berangkat dari asumsi dasar, bahwa pembelajaran bahasa asing tidaklah jauh berbeda dengan belajar bahasa ibu, yaitu dengan penggunaan bahasa secara langsung dan intensif dalam komunikasi keseharian, dimana tahapannya bermula dari mendengarkan kata-kata, menirukan secara lisan, sedangkan mengarang dan membaca dikembangkan kemudian,.

Metode ini berorientasi pada pembentukan keterampilan pelajar agar mampu berbicara secara spontanitas dengan tata bahasa yang fungsional dan berfungsi untuk mengontrol kebenaran ujarannya, bak penutur asli.

Sekalipun metode langsung merupakan salah satu metode yang cukup efektif dalam pengajaran bahasa arab, namun tidak terlepas dari kelebihan dan kekurangan yang 
perlu dijadikan bahan evaluasi dalam praktek pembelajaran bahasa arab.

Pengalaman seorang guru dalam mengajar bahasa arab akan sangat berpengaruh dalam kemampuannya menanggulangi permasalahan-permasalahan yang dihadapi dalam penerapan metode langsung.

Metode langsung sangat relevan untuk diimplementasikan dalam pembelajaran bahasa arab di sekolah-sekolah Islam maupun pondok-pondok pesantren yang mengajarkan bahasa arab, terlebih jika sekolah Islam dan pondokpondok pesantren tersebut ingin mendorong siswa-siswanya untuk meneruskan studi di Timur Tengah.

Implementasi metode langsung dalam pengajaran bahasa arab dilaksanakan secara bertahap sesuai dengan kemampuan siswa, sehingga hasilnya akan efektif dalam meningkatkan kemampuan siswa dalam berbicara bahasa arab.

\section{DAFTAR PUSTAKA}

Abdul Hamid, Uril Baharuddin dan Bisri Mustofa, Pembelajaran Bahasa Arab Pendekatan, Metode, Strategi, Materi, dan Media, UIN Malang Press, 2008

Abdul Majid, Perencanaan Pembelajaran

Mengembangkan Standar

Kompetensi

Guru, Remaja Rosdakarya, Bandung, 2007

Abdul Munip, dkk, Al-'arabiyah Jurnal Pendidikan Bahasa Arab, Jurusan Pendidiakan Bahasa Arab Fakultas
Tarbiyah UIN Sunan Kalijaga

Yogyakarta, 2004

Bermawy Munthe, Kunci Praktis Desain Pembelajaran, UIN Sunan Kalijaga

Yogyakarta,CTSD,2009.

Cece Widjaya, dkk. Upaya Pembaharuan Dalam Pendidikan dan Pengajaran, Remaja Rosda karya: bandung. 1992

Djudju Sudjana S. Strategi Pembelajaran, Falah production : Bandung. 2000

Effendy, Ahmad Fuad, Metodologi Pengajaran Bahasa Arab. Misykat.Malang, 2009.

Furqonul Aziez dan Chaedar Alwasilah, Pengajaran Bahasa Komunikatif Teori dan Praktek, Rosdakarya, Bandung, 1996

Imron, Efektifitas Metode Langsung dalam Pengajaran Bahasa Arab di Kelas II Madrasah Aliyah Keagamaan

Raudhatul Ulum Sakatiga Indralaya OKI Sumatra Selatan, Skripsi, Fakultas Tarbiyah UIN Sunan Kalijaga, 2003

$\begin{array}{cr}\text { Iskandarwassid dan } & \begin{array}{c}\text { Dadang } \\ \text { Sunendar, }\end{array} \\ \text { Pembelajaran } & \text { Bahasa, } \\ \text { Remaja } & \text { Rosdakarya, } \\ \text { Bandung, 2008. } & \end{array}$

M. Basyiruddin Usman dan Asnawir, Media Pembelajaran, Delia Citra Utama, Jakarta, 2002 
Makrom Malibary dkk, Pedoman Pengajaran Bahasa Arab pada Perguruan TinggiAgama Islam IAIN, Jakarta, 1976.

Mulyanto Sumardi, Pengajaran Bahasa Asing Sebuah Tinjauandari Segi Metodologi, Kramat Kwitang, Jakarta, 1974.

Nunung Nuraeni, Methode dalam Pembelajaran Bahasa Arab di Pesantren Ibnul Qoyyim Yogya, Skripsi, Fakultas Tarbiyah UIN Sunan Kalijaga, 2002

Qaimah, Pembelajaran Bahasa Arab dengan Metode Langsung di Pondok Pesantren Putra Ibnul Qoyyim Tegalyoso Stimulyo Piyungan Bantul, Skripsi, Fakultas Tarbiyah UIN Sunan Kalijaga, 2008.

Radliyah Zaenuddin, dkk, Metodologi dan Strategi Alternatif Pembelajaran Bahasa Arab, Pustaka Rihlah Group, Cirebon, 2005.

Umi machmudah dan Abdul wahab Rosyidi. Active Learning dalam Pembelajaran Bahasa Arab, Uin-malang press: Malang 2008

W.J.S Poerwadarminto. Kamus Besar Bahasa Indonesia. Balai Pustaka : Yogyakarta. 1989 